\title{
DETERMINATION OF HARVESTING LOSSES, FIELD CAPACITY AND ENERGY CONSUMPTION FOR DIFFERENT RICE COMBINE HARVESTERS
}

\author{
R. A. Hegazy ${ }^{1}$
}

\begin{abstract}
According to the type and specification of each combine harvester, losses, field capacities and energy required may vary. Hence, studying different parameters which may cause losses and affect combine performance are important. So, field evaluation to measure combine losses, fuel consumption and field capacity was conducted at International Rice Research Institute, Los Baños, Philippines during dry season 2014. Four different rice combine harvesters with different threshing systems and configurations including one head-feed combine (Kubota ER 232) and three whole-crop combines [Wintersteiger, CLAAS Crop Tiger: axialtangential flow (TAF) and Thai combine] were assessed on split-split two level randomized block design with four replications. Each combine operated under two levels of forward speeds (lower and higher) to harvest two different rice varieties (NSIC RC222 and NSIC RC238). Measurements for each combine included major components of losses [shattering losses, blower/screen losses (rear-end losses) and unstrapped losses] and field capacity. Fuel consumption was recorded for Kubota and CLAAS combine. All combine Harvesters run under same harvesting condition. Results revealed that average values of shattering and unstrapped losses ranged from 1 to 24.11 and from 0.12 to $7.22 \%$ of yield respectively. All combine harvesters lead up to cause higher shattering losses when operated at lower speeds compared to higher speeds. Maximum blower/screen losses (rear-end losses) recorded was $2.26 \%$ of yield by using CLAAS to harvest NSIC RC238, while minimum value was $0.24 \%$ of yield and obtained when Kubota harvested NSIC RC238 variety. The maximum averages of blower/screen losses (rear-end losses) value recorded with Wintersteiger and Thai combines were 1.04 and $1.58 \%$ of yield respectively. Average harvesting capacity were 0.473 , 0.424, 0.400 and 0.380 ha $h^{-1}$ for Kubota, Thai, Wintersteiger and Class
\end{abstract}

\footnotetext{
${ }^{1}$ Assistant Professor, Agric. Eng. Dept., Faculty of Agric., Kafrelsheikh University
} 
combine respectively when operated at higher forward speed to harvest both varieties. For CLAAS combine, fuel consumption varied from 52.481 to $100.191 \mathrm{l} \mathrm{ha}^{-1}$, while for Kubota, fuel consumption varied from 7.396 to $29.586 \mathrm{l} \mathrm{ha}^{-1}$. Minimum engine power required to run Kubota and its consumed energy were $7.94 \mathrm{hp}$ and $23.37 \mathrm{~kW} . \mathrm{h} \mathrm{ha} \mathrm{h}^{-1}$ respectively when harvested NSIC RC238, maximum engine power required was 23.66 when Kubota used to harvest NSIC RC222 with $93.49 \mathrm{~kW} . \mathrm{h} \mathrm{ha} \mathrm{h}^{-1}$ consumed energy. For CLAAS, minimum engine power required was $27.66 \mathrm{hp}$ to harvest NSIC RC238 at higher speed with $165.84 \mathrm{~kW} . \mathrm{h} \mathrm{ha} a^{-1}$ consumed energy, while the maximum engine power required was $45.32 \mathrm{hp}$ to harvest NSIC RC222 at lower speed with $316.6 \mathrm{~kW} . \mathrm{h} \mathrm{ha} \mathrm{h}^{-1}$ consumed energy.

Keywords: Combine harvesters, harvesting losses, rice crop, field capacity, energy required.

\section{INTRODUCTION}

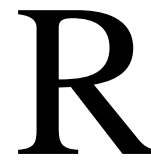
ice is the world's most important food staple and $90 \%$ of the riceproducing area is located in Asia. It is a major source of livelihood for farmers, especially in low-income and lowermiddle-income countries (Dawe et al. 2010; Pandey et al. 2010). Rice combine harvesters are playing a more important role in harvesting and are being widely used. Now the sales and use of combine harvesters are expanding very rapidly in the Asian region, e.g number of combine harvesters increased from 947 in 2010 to 2935 units in 2012 in Cambodia (Saruth, 2011; MAFF, 2013). Number of combine harvesters recorded in Bangladesh was 100 in 2011 compared to 30 units in 2008 (AbdulWohab, 2011; Ahmed and Matin, 2008), Number of combine harvesters being used in Thailand is around 41143 and 600 is the yearly local production (NSO, 2010). The percentage of rice harvested by combine reached $15 \%$ in Vietnam and 10\% in Philippines (Viet, 2012; Mariano et al., 2012). In Egypt, number of combine harvesters being used in 2008 was 3161 units according to Food and Agriculture Organization of the United Nations (FAO) (FAO, 2014). For countries which has higher mechanization index like Japan, Korea, China and India, the number of combine harvesters and the percentage of rice harvested area by them is 
higher. Different combine harvesters have been introduced with different specification, threshing and cleaning systems. Japan developed and introduced small head feed rice combines which are designed to harvest Japonica varieties and they were widely used in Japan, Taiwan, Korea and many countries (Chang, 1986). Thailand introduced a big axial flow thresher based combines with 130-190 hp diesel engine and uses cutterbar system of Western combines in its harvesting unit which considered big compared to other combines (Kalsirisilp and Singh, 1998). IRRI has been using it in its experimental farm in Los Baños, Philippines since mid1990s (Gummert and Hien, 2013). CLAAS introduced different combine harvesters including small, medium and multi-purpose combine harvester e.g Crop Tiger to be operated in smaller size rice farms in Asia, and powered by 58-86 hp 4-cylinder diesel engines with different mobility systems (CLAAS Vision, 1998). However, the major design concepts and use of all combine harvesters remain to minimize crop losses that occur while using the machine.

For losses tracking under different conditions, El-Nakib et al. (2003) used Kubota combine as a mechanical harvester of rice crop (Sakha 102). They found that header, threshing, separating and shoe losses increased with the increase of the forward speed and the decrease of grain moisture content. And also they found that optimum operating parameters for harvesting rice crop were, combine forward speed of $4.5 \mathrm{~km} \mathrm{~h}^{-1}$ and grain moisture content of $16.5 \%$. Badr (2005) indicated that increasing the forward speed from 1.0 to $4.0 \mathrm{~km} \mathrm{~h}^{-1}$ at a constant moisture content of 22 $\%$, increased field capacity from 0.31 to $1.14 \mathrm{fed} \mathrm{h}^{-1}$ while decreased field efficiency from 89.3 to $82.7 \%$ with using Yanmar combine. ElSharabasy (2006) indicated that increasing machine forward speed from 1.5 to $3.0 \mathrm{~km} / \mathrm{h}$ increased effective field capacity from 0.277 to 0.452 ; 0.251 to $0.382 ; 0.208$ to 0.349 and 0.181 to $0.296 \mathrm{fed} \mathrm{h}^{-1}$ at different grain moisture contents of 21.45, 22.20, 23.12 and $24.60 \%$, respectively. Abdelmotaleb et al. (2009) showed that the increase of combine forward speed form 0.8 to $2.5 \mathrm{~km} \mathrm{~h}^{-1}$ leads to decrease the field efficiency from 84.96 to $62.35 \%$ at cutting height of $0.2 \mathrm{~m}$ using the combine without control system. The other cutting heights and combine systems had the same above mention trend. Other researchers examined field performance 
of different combine harvesters. Kalsirislip and Singh (1999) reported that in a combine equipped with a $3 \mathrm{~m}$ width head stripper, field capacity and field efficiency were $0.66 \mathrm{ha} \mathrm{h}^{-1}$ and $74 \%$ for standing crop and $0.3 \mathrm{ha}$ $\mathrm{h}^{-1}$ and $72 \%$ for lodged crop, respectively. Fouad et al. (1990) studied a self-propelled rice combine harvester and reported that raising travel speed from 0.8 to $2.9 \mathrm{kmh}^{-1}$ increased grain losses but decreased field efficiency of the combine.

So, the main objective of this study was to evaluate different combine harvesters in rice field to track losses and variables may affect them, the evaluation included recoding the percentage of losses for different four combine harvesters and observing energy required for two whole-crop and head-feed combine harvesters.

\section{MATERIALS AND METHODS}

\section{Site, Soil Specification and Harvesting Conditions}

Field evaluation to measure combine losses, fuel consumption and field capacity was conducted at experimental farm within the Experimental Station of the International Rice Research Institute (IRRI) in Los Baños, Laguna, Philippines. The site has a slope of $1 \%$ with northeasterly aspect, and an elevation of $27 \mathrm{~m}$ above sea level. The soils are Lithic Haplustept (Soil Survey Staff, 2010) varying in texture from loam to clay and overlying volcanic tuff evident at $0.3 \mathrm{~m}$ to $1.2 \mathrm{~m}$ depth. At harvesting time, wind speed was $2.7 \mathrm{~m} \mathrm{~s}^{-1}$ with direction to NNW. Mean temperature was $28.7^{\circ} \mathrm{C}$ with radiation of $21.8 \mathrm{MJ} \mathrm{m}^{-2}$ and 87.1 relative humidity (Climate Unit, Crop and Environmental Science Division, International Rice Research Institute).

The field was prepared and mechanically transplanted with two varieties of rice NSIC RC222 (a semi-dwarf, high yielding shattering lowland irrigated variety) and NSIC RC 238 with flood irrigation system along with the season. The site was historically cropped with paddy rice prior to the experiment. $50-60 \mathrm{~kg}$ seed $\mathrm{ha}^{-1}$ rate has been used to raise seedlings and planting on 18 December in 2013. Fertilizers were applied basally at $40 \mathrm{~kg} \mathrm{~N} \mathrm{ha}{ }^{-1}, 17 \mathrm{~kg} \mathrm{P} \mathrm{ha}^{-1}$, and $33 \mathrm{~kg} \mathrm{~K} \mathrm{ha}^{-1}$ as granular fertilizers, additional urea fertilizer was with totaling $150 \mathrm{~kg} \mathrm{~N} \mathrm{ha}^{-1}$. 
Four different rice combine harvesters with different threshing systems and were operated to measure losses component which are shattering loss, blower/screen losses and unstrapped loss. Specifications of each combine used in the study are listed below in table 1:

Table1 1: Combines used in experiments and their specifications

\begin{tabular}{|c|c|c|c|c|}
\hline Combine & Kubota & Wintersteiger & CLAAS & Thai combine \\
\hline Type & head-feed & whole-crop & whole-crop & $\begin{array}{c}\text { whole-crop (axial } \\
\text { flow combine } \\
\text { harvester) }\end{array}$ \\
\hline Model & ER 323 & $\begin{array}{c}\text { Delta } \\
\text { Plot combine }\end{array}$ & $\begin{array}{c}\text { Crop Tiger } 30 \text { Terra } \\
\text { Trac }\end{array}$ & KPH-22T \\
\hline $\begin{array}{l}\text { Total length, } \\
\text { mm }\end{array}$ & 3470 & 6000 & 5855 & 6300 \\
\hline All width, mm & 1690 & 2200 & 2620 & 3200 \\
\hline $\begin{array}{l}\text { Overall } \\
\text { height, } \mathrm{mm}\end{array}$ & 1980 & 2750 & 2905 & 3470 \\
\hline Mass, kg & 2800 & 3500 & 4270 & 9000 \\
\hline Engine & $\begin{array}{l}67 \mathrm{HP} \text { at } 2700 \\
\text { rpm } 3 \text { cylinder } \\
\text { vertical water } \\
\text { cooled engine }\end{array}$ & $\begin{array}{l}84 \text { HP } 3.31 \text { capacity } \\
\text { turbo water cooled } \\
\text { Perkins engine }\end{array}$ & $\begin{array}{l}86 \text { HP BS-III } \\
\text { emissions standard- } \\
\text { cylinder water } \\
\text { cooled engine }\end{array}$ & $\begin{array}{l}207 \text { HP water } \\
\text { cooled } 6 \\
\text { cylinders, } 24 \\
\text { valve engine }\end{array}$ \\
\hline Fuel & \multicolumn{4}{|c|}{ Diesel } \\
\hline $\begin{array}{l}\text { Year in } \\
\text { service }\end{array}$ & 2 & 1 & 2 & 5 \\
\hline $\begin{array}{c}\text { Threshing } \\
\text { and cleaning } \\
\text { systems }\end{array}$ & $\begin{array}{l}\text { Threshing } \\
\text { principle: Head } \\
\text { feed with rasp } \\
\text { bars } \\
\text { Threshing } \\
\text { cylinder: } 550 \mathrm{~mm} \text { - } \\
1760 \mathrm{~mm} \\
\text { re-thresher: } 195 \\
\text { mm-900 mm, } \\
\text { Cleaner: chaffer } \\
\text { sieve + fan ( front } \\
\text { blowing and rear } \\
\text { suction) + two } \\
\text { times vibrate }\end{array}$ & $\begin{array}{l}\text { Threshing principle } \\
\text { Concave : } 10 \\
\text { concave bars, } \\
\text { threshing drum } \\
\text { diameter: } 350 \mathrm{~mm} \text {, } \\
\text { threshing drum } \\
\text { width: } 780 \mathrm{~mm} \text {, } \\
\text { speed adjustment: } \\
\text { electrically } \\
\text { adjustable, variator: } \\
330 \text { - } 1900 \mathrm{rpm} \\
\text { stepless } \\
\text { beater bars } 6 \text { units, } \\
\text { Shakers Area: } 1.8 \\
\mathrm{~m}^{2}, 2 \text { drop stages, } \\
\text { including suspended } \\
\text { guide plates, } \\
\text { cleaning blower } \\
\text { hydraulically driven }\end{array}$ & $\begin{array}{l}\text { Threshing principle: } \\
\text { Tangential axial } \\
\text { flow (TAF) } \\
\text { With Pegteeth } \\
\text { Cleaning system: } \\
\text { forced air-cleaning } \\
\text { fan, } 2 \text { speeds, } 1200 \\
\text { and } 1500 \mathrm{rpm} \text {, } \\
\text { controlled by fan } \\
\text { shutter, cleaning } \\
\text { area: } 1.24 \mathrm{~m}^{2} \text { (upper } \\
\text { and lower sieves) }\end{array}$ & $\begin{array}{l}\text { Threshing } \\
\text { principle: } \\
\text { axial flow } \\
\text { Upper threshing } \\
\text { tank } \\
: 1615 \mathrm{~mm} \text {, Paddy } \\
\text { thresher diameter } \\
560 \mathrm{~mm} \text {, upper } \\
\text { threshing tank } \\
\text { can be separated }\end{array}$ \\
\hline
\end{tabular}




\section{Losses Measurement}

Losses measurements done for all combine harvesters when operated with advance low and high velocity selected by the operator using a speed selection lever and also measurable during operation by recording the time required for the harvester in a given distance.

To determine harvesting losses, catching frames made of sackcloth with $300 \times 300 \mathrm{~mm}^{2}$ to be placed between the rows of plants before harvesting the field. After harvesting, all the grains found on the frames are collected and weighed, this amount of grains represent the shattering losses (header losses) and in which rear-end losses are prevented from falling onto the ground in the wake of the harvester. Rear-end losses (blower/screen losses) were determined by collected all discharged straw by using a net carried by two people who followed the harvester and walking behind/beside the machine (Figure 1). The collected grain cleaned by hand to separate the grains that were blown over and its amount calculated. For third type of losses, rice grain that remained on standing straw after field harvesting were observed and collected to be the unstrapped loss.

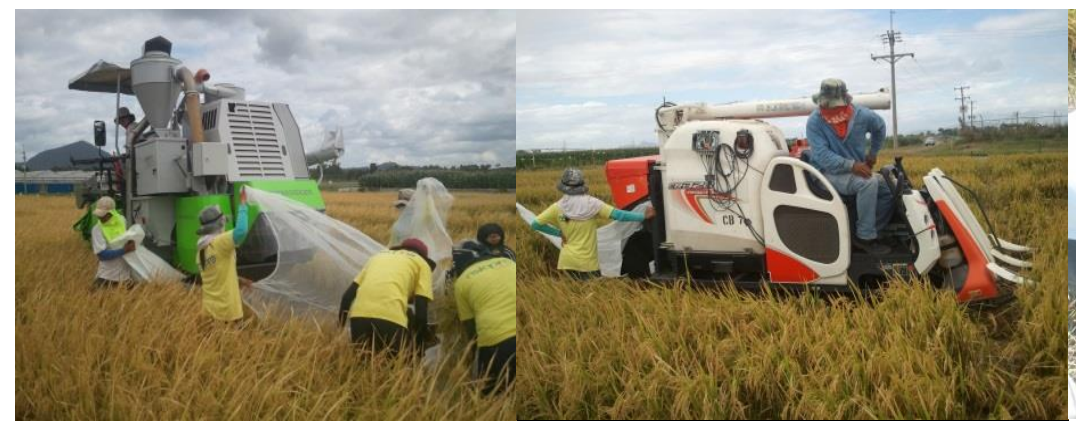

Rear-end losses (blower/screen losses)

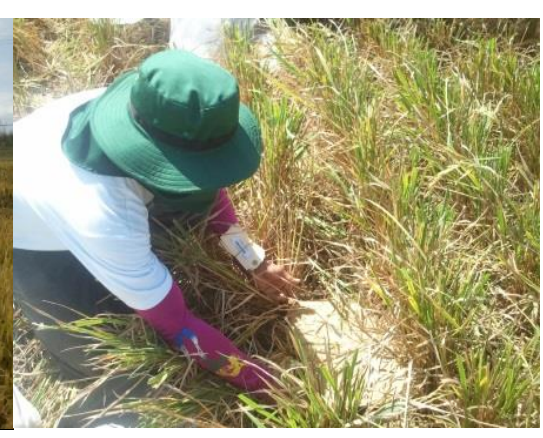

Shattering loss

Figure 1: Two type of harvesting losses; rear-end losses and shattering losses

\section{Experimental Design}

Split-split two level randomized block design with four replications was used. Area of $36 \times 100 \mathrm{~m}^{2}$ was divided into two sub-plots $48 \times 36 \mathrm{~m}^{2}$ each, each sub-plot divided into 32 sub-sub-plots with $4.5 \times 12 \mathrm{~m}^{2}$ each. Combine harvester operated under two levels of forward speeds (lower and higher) to harvest two different rice varieties (NSIC RC222 and NSIC RC238) as the two study variables. All combine Harvesters run under same harvesting condition and components of combines kept constant including the reel rotational velocity, cutter bar speed, reel index, feed 
rate etc. Yield component sampling at maturity stage done for $0.3 \times 2$ rows area in four locations, while grain yield sampling done in 32 subsub-plots within 9 rows $x 2.5 \mathrm{~m}$ area.

Fuel consumption of Kubota and CLAAS combine harvester was recorded using flow meter sensors attached to the engine. An electronic board was used to receive and save digital pulses sent by the flow meter sensors. One of the sensors was installed where fuel enters the injector pump; another flow meter was located where fuel returns to the tank. All fuel data recorded on the device memory and also manually recorded.

Power/energy requirement was identically based on fuel consumed. To estimate the engine power, the following formula was used (Hunt, 1983).

Where:

$$
\mathrm{EP}=\mathrm{Fc} \times\left(\frac{1}{60 \times 60}\right) \mathrm{PE} \times \mathrm{L} . \mathrm{C} . \mathrm{V} \times 427 \times \frac{1}{75} \times \frac{1}{1.36} \eta_{\mathrm{th}} \eta_{\mathrm{m}}
$$

Fc: Fuel consumption, $1 / \mathrm{h}$.

PE: Density of diesel fuel $\mathrm{kg} / \mathrm{l}$ (for Gas oil $=0.85$ and Gasoline $=0.72$ )

L.C.V: the lower calorific value of fuel, $(11000 \mathrm{k} . \mathrm{cal} / \mathrm{kg})$.

427: Thermo-mechanical equivalent, (kg.m/k.cal).

$\eta_{\mathrm{thb}}$ : Thermal efficiency of the engine (35\% for Diesel)

$\eta_{\mathrm{m}}$ : Mechanical efficiency of the engine ( $80 \%$ for Diesel)

The consumed energy can be calculated as following:

Engine power $=3.16 \mathrm{Fc}, \mathrm{kW}$

Field capacity was calculated after recording harvesting time in specific area with speed and width. The experimental data was analyzed statistically by analysis of variance (ANOVA) method, critical difference at 1 and 5 per cent level of significance observed for testing significance of difference between the different treatments.

\section{RESULTS AND DISCUSSION}

\section{Harvesting Losses}

\subsection{Shattering Losses}

All combine harvesters tended to cause shattering losses under the two rice varieties and within the two ranges of forward speeds. Average value of shattering losses varied from 1 up to $24.11 \%$ of yield as minimum and maximum average value respectively. Higher shattering losses observed when all combine harvesters operated at lower speeds compared to higher speeds except for Thai combine (Figure 2a). This matching with the recommendation to adopt proper harvesting speed because when travel 
speeds are too slow may increase header loss due to an inconsistent flow of material or repeated working cycles at the header.

Using Thai combine, Kubota, Wintersteiger and CLAAS gave average of $22.44,7.37,6.88$ and $6.33 \%$ losses of yield as shattering losses respectively under different combines' forward speeds for NSIC RC222. While using same combines gave 17.43, 7.93, 4.36 and $9.16 \%$ losses of yield as shattering losses respectively for NSIC RC238 (Figure 2b). It was clear from data that average values of NSIC RC238 shattering losses were less than NSIC RC222 when harvested by Thai and Wintersteiger combine, but with using both CLAAS and Kubota combines, the shattering losses in NSIC RC238 increased by $44.7 \%$ and $7.6 \%$ respectively compared to rice variety NSIC RC222. That is may be because of lower grain moisture content at harvesting time for both verities which was $22.1 \%$ in average.

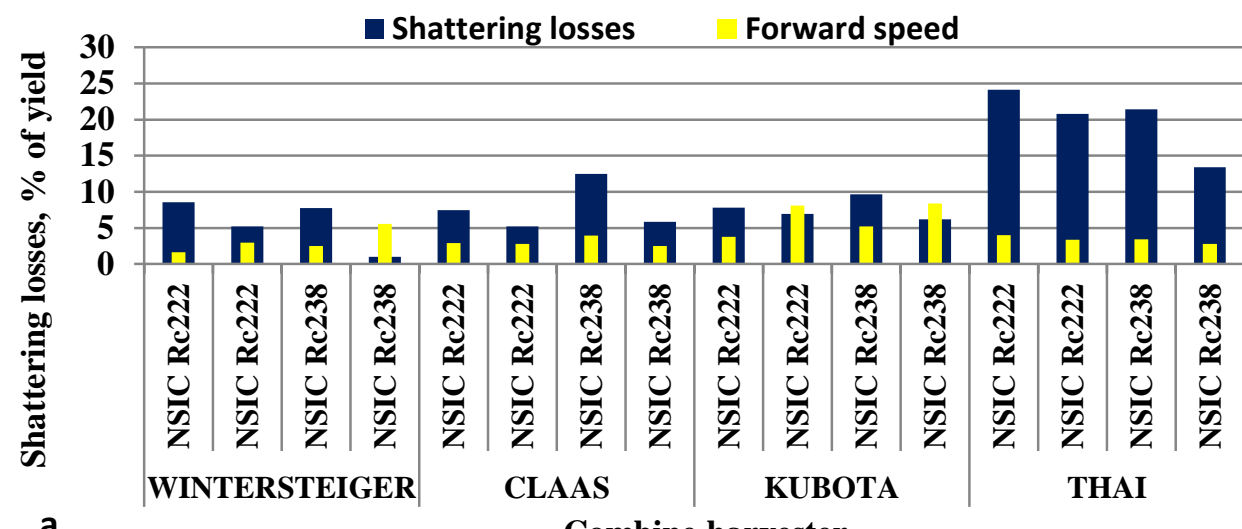

10.00

8.00

6.00

4.00

2.00

0.00

Combine harvester
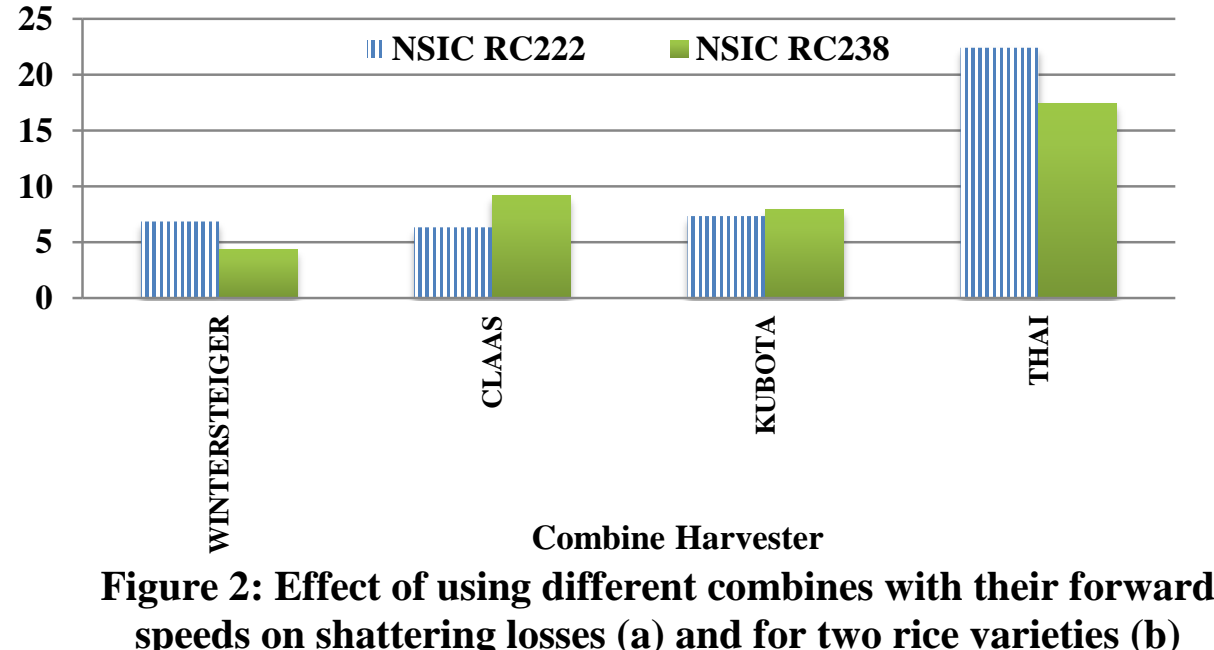
Analysis of variance (ANOVA), multiple comparison tests and model analysis (Type III SS) for shuttering losses showed that the standard deviation value was 7.687 with 0.736 coefficient of determination. Both combine harvester and harvesting speed had significant effect on shuttering losses, while verities have no significant effect on shuttering losses. For Comparison tests, the three combines; Wintersteiger, Kubota and CLAAS had significant differences to reduce shattering losses values against Thai combine but not with each other. There was significant differences too when they are operated in two different speed ranges, while the differences in shattering values was not significant within both varieties (Table 2).

Table 2: Multiple comparison tests for the variables: Tukey (HSD) / Fisher (LSD) analysis of the differences between groups with a confidence range of $95 \%$ for shattering loss

\begin{tabular}{|l|c|c|c|c|c|}
\hline Variable & $\begin{array}{c}\mathrm{R} \text { (coefficient } \\
\text { of correlation) }\end{array}$ & $\begin{array}{c}\mathrm{R}^{2} \text { (coefficient of } \\
\text { determination) }\end{array}$ & $\begin{array}{c}\mathrm{R}^{2} \text { adj. (adjusted } \\
\text { coefficient of } \\
\text { determination) }\end{array}$ & Mean & $\begin{array}{c}\text { Standard } \\
\text { deviation }\end{array}$ \\
\hline Shattering loss & 0.858 & 0.736 & 0.654 & 10.212 & 7.687 \\
\hline Comparison tests for the variable: Harvester \\
\hline Categories & Difference & $\begin{array}{c}\text { Standardized } \\
\text { difference }\end{array}$ & $\begin{array}{c}\text { Critical value } \\
\text { HSD/Fisher } \\
\text { (LSD) }\end{array}$ & $\begin{array}{c}\text { Pr. > Diff } \\
\text { Tukey (HSD) } \\
\text { /Fisher (LSD) }\end{array}$ & Significant \\
\hline Thai * Wintersteiger & 13.152 & 8.224 & $2.661 / 2.011$ & $<0.0001$ & Yes \\
\hline Thai * Kubota & 11.658 & 7.289 & $2.661 / 2.011$ & $<0.0001$ & Yes \\
\hline Thai * CLAAS & 11.560 & 7.228 & $2.661 / 2.011$ & $<0.0001$ & Yes \\
\hline CLAAS * Wintersteiger & 1.592 & 0.996 & $2.661 / 2.011$ & $0.753 / 0.324$ & No \\
\hline CLAAS * Kubota & 0.098 & 0.061 & $2.661 / 2.011$ & $1.000 / 0.951$ & No \\
\hline Kubota * Wintersteiger & 1.495 & 0.934 & $2.661 / 2.011$ & $0.787 / 0.355$ & No \\
\hline Comparison tests for the variable: variety, Tukey (HSD) and Fisher (LSD) \\
\hline NSIC RC238* NSIC RC222 \\
\hline \multicolumn{7}{|l|}{0.988} & 0.874 & 2.011 & 0.387 & No \\
\hline Multiple comparison tests for the variable: Speed, Tukey (HSD) and Fisher (LSD) & Yes \\
\hline S1*S2 & 6.346 & 5.612 & 2.011 & $<0.0001$ & \\
\hline
\end{tabular}

\subsection{Rear-end and Unstrapped Losses}

For both rear-end losses and unstrapped losses, there was no clear trend for losses variation with the forward speed, as rear-end losses depend more on the threshing and cleaning systems and their components. Data showed that maximum rear-end losses recorded was $2.26 \%$ of yield by using CLASS to harvest NSIC RC238, while minimum value was $0.24 \%$ of yield and obtained when Kubota harvested NSIC RC238. The 
maximum averages rear-end losses value recorded with Wintersteiger and Thai combines were 1.04 and $1.58 \%$ of yield respectively (Table 3 ).

Although, the unstrapped losses not correlated to combines entire components, considerable amount of losses recorded and even higher than rear-end losses in some plots, $4.19 \%$ of yield unstrapped losses observed with harvesting NSIC RC238 by Thai combine. Grand averages of unstrapped losses values under all combines for both varieties were 2.71, 2.35, 1.21 and 1.01 for Thai, Wintersteiger, Kubota and CLAAS respectively (Table 3 and Figure 3). A trend of increasing unstrapped losses appeared when NSIC RC222 got harvested at higher speed by Thai, Wintersteiger and Kubota, which could be related to unfavorable high harvesting speed, but still cannot be a general trend, same time unstrapped losses observed in-between harvesting width as well as in both sides of each combine, that is may a reason to involve the drivers and their abilities to control the harvesting path.

Table 3: Rear-end and unstrapped losses for different combine harvesters

\begin{tabular}{|l|l|c|c|c|}
\hline \multirow{4}{*}{ Combine types } & Rice Varieties & $\begin{array}{c}\text { Average } \\
\text { Speed, } \\
\text { km h }^{-1}\end{array}$ & $\begin{array}{c}\text { Average } \\
\text { Rear-end } \\
\text { losses, \% }\end{array}$ & $\begin{array}{c}\text { Average } \\
\text { Unstrapped } \\
\text { Losses, \% }\end{array}$ \\
\hline \multirow{4}{*}{ Wintersteiger } & NSIC RC222 & 0.55 & 1.00 & 2.12 \\
\cline { 2 - 5 } & NSIC RC222 & 0.99 & 0.93 & 2.96 \\
\cline { 2 - 5 } & NSIC RC238 & 0.84 & 1.04 & 3.03 \\
\cline { 2 - 5 } & NSIC RC238 & 1.85 & 0.85 & 1.30 \\
\hline \multirow{4}{*}{ Kubota } & NSIC RC222 & 0.96 & 1.76 & 2.09 \\
\cline { 2 - 5 } & NSIC RC222 & 0.93 & 0.50 & 0.16 \\
\cline { 2 - 5 } & NSIC RC238 & 1.31 & 2.26 & 1.29 \\
\cline { 2 - 5 } & NSIC RC238 & 0.84 & 1.49 & 0.48 \\
\hline \multirow{4}{*}{ Thai } & NSIC RC222 & 1.25 & 1.03 & 0.82 \\
\cline { 2 - 5 } & NSIC RC222 & 2.71 & 1.15 & 2.35 \\
\cline { 2 - 5 } & NSIC RC238 & 1.74 & 0.24 & 0.77 \\
\cline { 2 - 5 } & NSIC RC238 & 2.81 & 1.05 & 0.90 \\
\cline { 2 - 5 } & NSIC RC222 & 1.33 & 0.59 & 2.40 \\
\cline { 2 - 5 } & NSIC RC222 & 1.12 & 1.23 & 2.97 \\
\cline { 2 - 5 } & NSIC RC238 & 1.14 & 1.14 & 4.19 \\
\cline { 2 - 5 } & NSIC RC238 & 0.94 & 1.58 & 1.30 \\
\hline
\end{tabular}




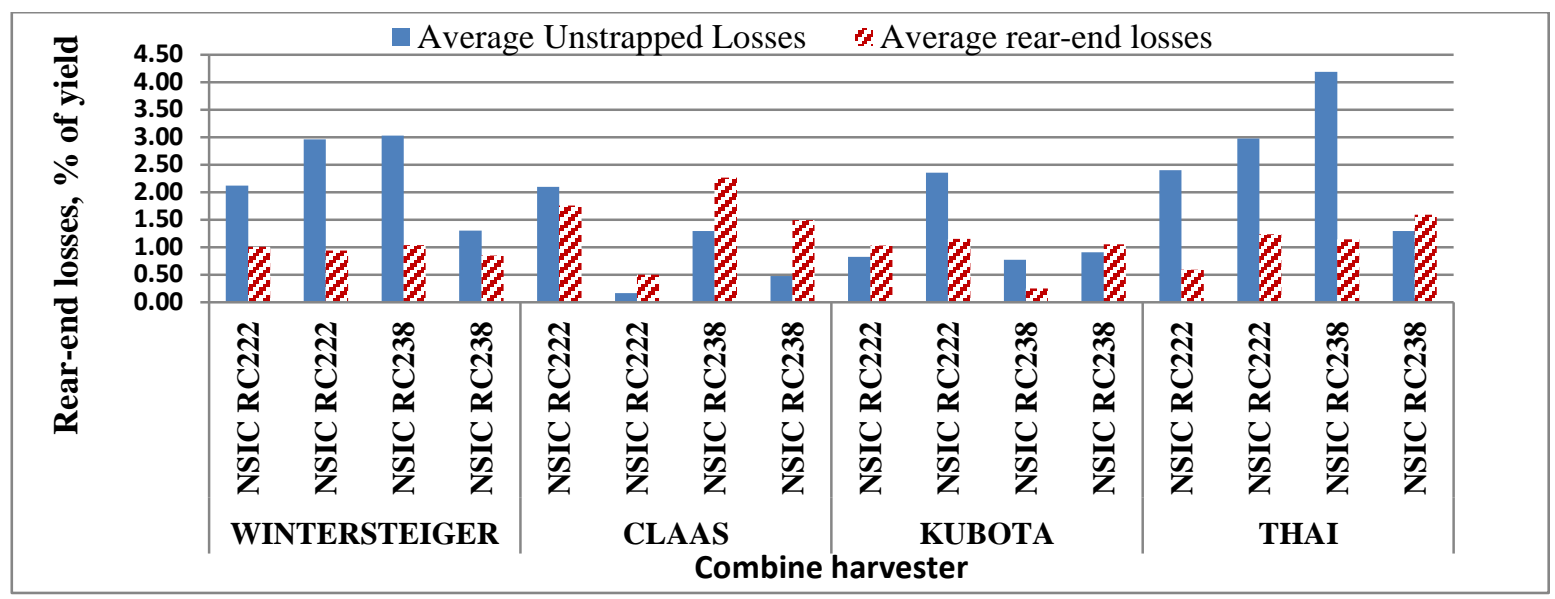

Figure 3: Rear-end and unstrapped losses for different combine harvesters Model analysis for rear-end losses showed no significant effects for the the variables, the standard deviation value was 0.718 with 0.558 coefficient of determination. Comparison tests (LSD) showed no trend for significant differences in rear-end losses values within the combine, also there was no significant differences in the value of rear-end losses either with the two speed ranges or varaieties (Table 4).

Table 4: Multiple comparison tests for the variables: Tukey (HSD) / Fisher (LSD) analysis of the differences between groups with a confidence range of $95 \%$ for Rear-end loss (Threshing loss)

\begin{tabular}{|c|c|c|c|c|c|}
\hline Variable & $\begin{array}{c}\mathrm{R} \\
\text { (coefficient } \\
\text { of } \\
\text { correlation) }\end{array}$ & $\begin{array}{l}\mathrm{R}^{2} \text { (coefficient } \\
\text { of } \\
\text { determination) }\end{array}$ & $\begin{array}{l}\mathrm{R}^{2} \mathrm{adj} \text {. (adjusted } \\
\text { coefficient of } \\
\text { determination) }\end{array}$ & Mean & $\begin{array}{l}\text { Standard } \\
\text { deviation }\end{array}$ \\
\hline $\begin{array}{l}\text { Rear-end loss (Threshing } \\
\text { loss) }\end{array}$ & 0.747 & 0.558 & 0.419 & 1.162 & 0.718 \\
\hline \multicolumn{6}{|c|}{ Comparison tests for the variable: Harvester } \\
\hline Categories & Difference & $\begin{array}{l}\text { Standardized } \\
\text { difference }\end{array}$ & $\begin{array}{l}\text { Critical value } \\
\text { HSD/Fisher } \\
\text { (LSD) }\end{array}$ & $\begin{array}{c}\text { Pr. > Diff } \\
\text { Tukey (HSD) } \\
\text { /Fisher } \\
\text { (LSD) }\end{array}$ & $\begin{array}{c}\text { Significant } \\
\text { (HSD)/Fisher } \\
\text { (LSD) }\end{array}$ \\
\hline CLAAS $*$ Kubota & 0.631 & 3.263 & $2.661 / 2.011$ & $0.011 / 0.002$ & Yes \\
\hline CLAAS * Wintersteiger & 0.500 & 2.584 & $2.661 / 2.011$ & $0.060 / 0.013$ & No/yes \\
\hline CLAAS * Thai & 0.220 & 1.137 & $2.661 / 2.011$ & $0.668 / 0.261$ & No \\
\hline Thai * Kubota & 0.411 & 2.125 & $2.661 / 2.011$ & $0.160 / 0.039$ & $\mathrm{No} /$ yes \\
\hline Thai * Wintersteiger & 0.280 & 1.446 & $2.661 / 2.011$ & $0.478 / 0.155$ & No \\
\hline Wintersteiger $*$ Kubota & 0.131 & 0.679 & $2.661 / 2.011$ & $0.904 / 0.500$ & No \\
\hline \multicolumn{6}{|c|}{ Comparison tests for the variable: variety, Tukey (HSD) and Fisher (LSD) } \\
\hline NSIC RC238 * NSIC RC222 & 0.099 & 0.725 & \begin{tabular}{l|l}
2.011 & \\
\end{tabular} & 0.472 & No \\
\hline \multicolumn{6}{|c|}{ Multiple comparison tests for the variable: Speed, Tukey (HSD) and Fisher (LSD) } \\
\hline $\mathrm{S} 1 * \mathrm{~S} 2$ & 0.049 & 0.358 & \begin{tabular}{l|l}
2.011 & \\
\end{tabular} & 0.722 & No \\
\hline
\end{tabular}


For unstrapped losses, the standard deviation value was 3.119 with 0.305 coefficient of determination. No significant effect observed with varaiables same as no significant differences. Except that (LSD) Comparison tests showed advanges of using both CLAAS and kubota to reduce unstarrped losses compared to Thai combine (Table 5).

Table 5: Multiple comparison tests for the variables: Tukey (HSD) / Fisher (LSD) analysis of the differences between groups with a confidence range of $95 \%$ for unstrapped loss.

\begin{tabular}{|c|c|c|c|c|c|}
\hline Variable & $\begin{array}{c}\mathrm{R} \text { (coefficient } \\
\text { of } \\
\text { correlation) }\end{array}$ & $\begin{array}{c}\mathrm{R}^{2} \text { (coefficient } \\
\text { of } \\
\text { determination) }\end{array}$ & $\begin{array}{l}\mathrm{R}^{2} \text { adj. (adjusted } \\
\text { coefficient of } \\
\text { determination) }\end{array}$ & Mean & $\begin{array}{l}\text { Standard } \\
\text { deviation }\end{array}$ \\
\hline Unstrapped loss & 0.552 & 0.305 & 0.083 & 2.163 & 3.119 \\
\hline \multicolumn{6}{|c|}{ Comparison tests for the variable: Harvester } \\
\hline Categories & Difference & $\begin{array}{l}\text { Standardized } \\
\text { difference }\end{array}$ & $\begin{array}{c}\text { Critical value } \\
\text { HSD/Fisher } \\
\text { (LSD) }\end{array}$ & $\begin{array}{c}\text { Pr. > Diff } \\
\text { Tukey } \\
(\text { HSD)/Fisher } \\
\text { (LSD) }\end{array}$ & $\begin{array}{c}\text { Significant } \\
\text { (HSD)/Fisher } \\
\text { (LSD) }\end{array}$ \\
\hline Thai * CLAAS & 2.590 & 2.413 & $2.663 / 2.012$ & $0.088 / 0.020$ & No/yes \\
\hline Thai $*$ Kubota & 2.441 & 2.312 & $2.663 / 2.012$ & $0.110 / 0.025$ & No/yes \\
\hline Thai * Wintersteiger & 0.996 & 0.943 & $2.663 / 2.012$ & $0.782 / 0.350$ & No \\
\hline Wintersteiger * CLAAS & 1.594 & 1.486 & $2.663 / 2.012$ & $0.454 / 0.144$ & No \\
\hline Wintersteiger * Kubota & 1.445 & 1.369 & $2.663 / 2.012$ & $0.525 / 0.178$ & No \\
\hline Kubota * CLAAS & 0.149 & 0.139 & $2.663 / 2.012$ & $0.999 / 0.890$ & No \\
\hline \multicolumn{6}{|c|}{ Comparison tests for the variable: variety, Tukey (HSD) and Fisher (LSD) } \\
\hline NSIC RC222 * NSIC RC & \begin{tabular}{l|l|}
8 & 0.216 \\
\end{tabular} & 0.287 & 2.012 & 0.776 & No \\
\hline \multicolumn{6}{|c|}{ Multiple comparison tests for the variable: Speed, Tukey (HSD) and Fisher (LSD) } \\
\hline $\mathrm{S} 1 * \mathrm{~S} 2$ & 0.664 & 0.882 & 2.012 & 0.382 & No \\
\hline
\end{tabular}

\section{Harvesting Capacity}

Average harvesting capacities $\left(\mathrm{ha}^{-1}\right.$ ) have been recorded for all combine harvesters. Maximum harvesting capacity recorded was $0.473 \mathrm{ha} \mathrm{h}^{-1}$ for Kubota when harvesting NSIC RC238 variety with higher forward speed, because of faster forward speed $\left(2.4 \mathrm{~km} \mathrm{~h}^{-1}\right)$ compared any other combine. Minimum value of average harvesting capacity was $0.104 \mathrm{ha} \mathrm{h}^{-1}$ and recorded with using Wintersteiger for harvesting NSIC RC238 with low forward speed (Figure 4). All harvesting capacities tended to logic trend with speed and width, but in some cases, CLAAS combine had plugging in the feeder house due to overfeeding when speed increased in 
some plots, that's the reason that harvesting capacity in case of higher speed appeared to be lower than its harvesting capacity with lower forward speed due the additional time needed for re-adjusting.

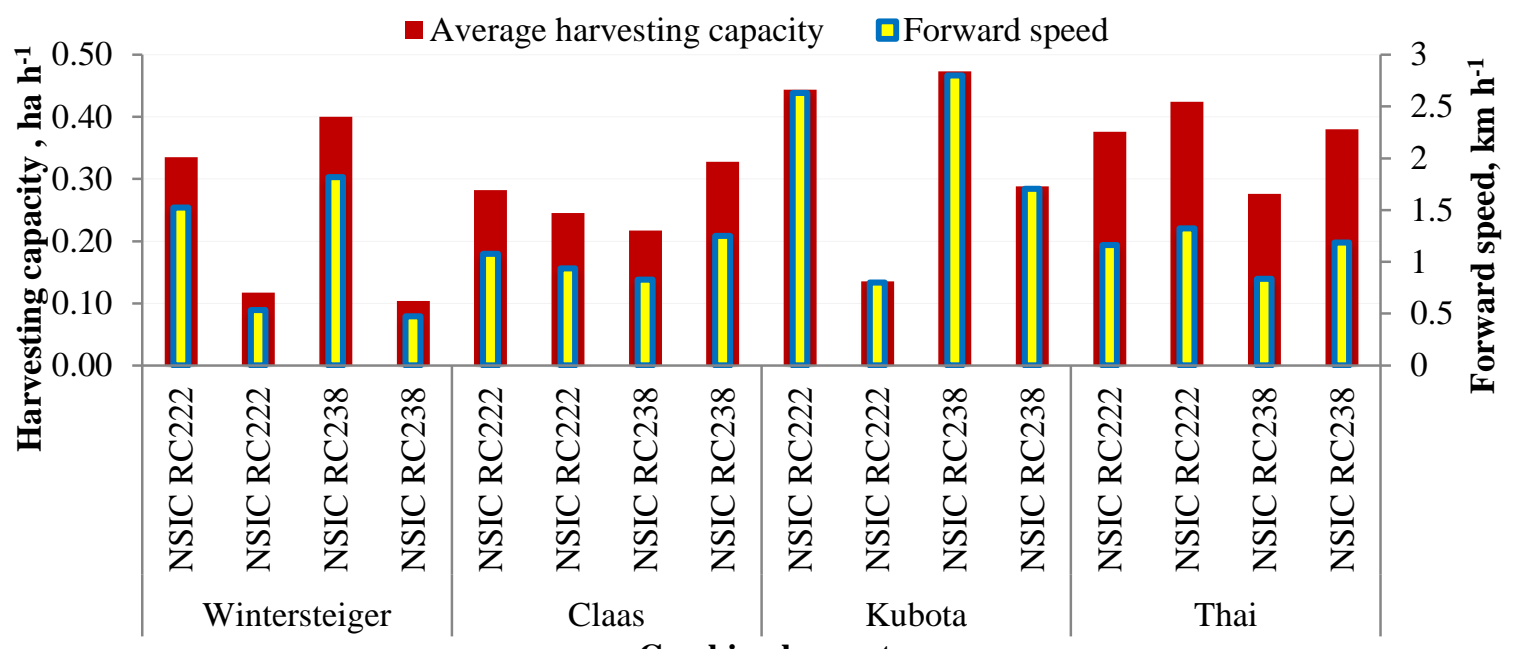

Combine harvester

Figure 4: Average values of harvesting capacities for different combine harvesters

Analysis of variance (ANOVA), multiple comparison tests and model analysis (Type III SS) for harvesting capacity showed that the standard deviation value was 0.116 with 0.871 coefficient of determination. Both combine harvester and harvesting speed had significant effect on harvesting capacity, while varieties have no significant effect on harvesting capacity. Even comparison tests showed significant differences in harvesting capacity values with both varieties, but there was no significant effect from ANOVA. Also, there was significant differences in harvesting capacity values with two harvesting speed ranges. Kubota Combine showed significant differences and advance for higher harvesting capacity compared to Wintersteiger and CLAAS combines, while Wintersteiger and CLAAS showed significant differences with better harvesting capacity compared to Thai (Table 6).

\section{Fuel Consumption, Engine Power and Consumed Energy}

Grand average of fuel consumption rate by CLAAS combine was 65.0121 $\mathrm{ha}^{-1}$, which is more than average fuel consumption rate for Kubota by $71.6 \%$ under different forward speeds and varieties. Generally, there are 
no significant differences in CLAAS fuel consumption either its running under high/ low forward speeds, but in Kubota fuel consumption data showed lower fuel consumption with higher speed compared to lower speeds (Figure 5).

Table 6: Multiple comparison tests for the variables: Tukey (HSD) / Fisher (LSD) analysis of the differences between groups with a confidence range of $95 \%$ for harvesting capacity

\begin{tabular}{|c|c|c|c|c|c|}
\hline Variable & $\begin{array}{l}\mathrm{R} \text { (coefficient } \\
\text { of correlation) }\end{array}$ & $\begin{array}{c}\mathrm{R}^{2} \text { (coefficient } \\
\text { of } \\
\text { determination) }\end{array}$ & $\begin{array}{l}\mathrm{R}^{2} \text { adj. (adjusted } \\
\text { coefficient of } \\
\text { determination) }\end{array}$ & Mean & $\begin{array}{l}\text { Standard } \\
\text { deviation }\end{array}$ \\
\hline Harvesting capacity & 0.933 & 0.871 & 0.831 & 0.303 & 0.116 \\
\hline \multicolumn{6}{|c|}{ Comparison tests for the variable: Harvester } \\
\hline Categories & Difference & $\begin{array}{l}\text { Standardized } \\
\text { difference }\end{array}$ & $\begin{array}{l}\text { Critical value } \\
\text { HSD/Fisher } \\
\text { (LSD) }\end{array}$ & $\begin{array}{c}\text { Pr. > Diff } \\
\text { Tukey (HSD) } \\
\text { /Fisher (LSD) }\end{array}$ & $\begin{array}{c}\text { Significant } \\
\text { (HSD)/Fisher } \\
\text { (LSD) }\end{array}$ \\
\hline Kubota $*$ Wintersteiger & 0.117 & 6.943 & $2.661 / 2.011$ & $<0.0001$ & Yes \\
\hline Kubota * CLAAS & 0.094 & 5.610 & $2.661 / 2.011$ & $<0.0001$ & Yes \\
\hline Kubota * Thai & 0.013 & 0.745 & $2.661 / 2.011$ & $0.878 / 0.460$ & No \\
\hline Thai * Wintersteiger & 0.104 & 6.198 & $2.661 / 2.011$ & $<0.0001$ & Yes \\
\hline Thai $*$ CLAAS & 0.082 & 4.865 & $2.661 / 2.011$ & $<0.0001$ & Yes \\
\hline CLAAS * Wintersteiger & 0.022 & 1.333 & $2.661 / 2.011$ & $0.547 / 0.189$ & No \\
\hline \multicolumn{6}{|c|}{ Comparison tests for the variable: variety, Tukey (HSD) and Fisher (LSD) } \\
\hline NSIC RC238* NSIC RC222 & \begin{tabular}{l|l} 
& 0.026 \\
\end{tabular} & 2.189 & 2.011 & 0.034 & Yes \\
\hline \multicolumn{6}{|c|}{ Multiple comparison tests for the variable: Speed, Tukey (HSD) and Fisher (LSD) } \\
\hline S1*S2 & \begin{tabular}{l|l} 
& 0.072 \\
\end{tabular} & 6.086 & 2.011 & $<0.0001$ & Yes \\
\hline
\end{tabular}

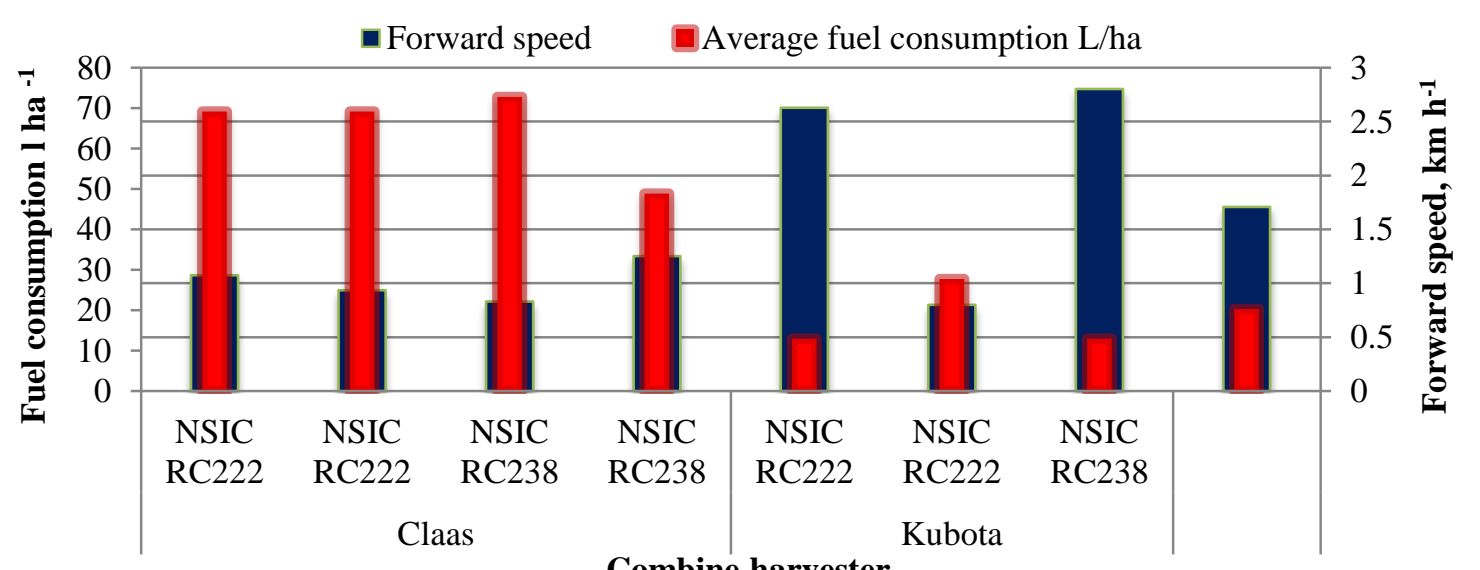

Combine harvester

Figure 5: Fuel consumption 
As the fuel consumed by CLAAS was higher, the required engine power and consumed energy were higher too, the minimum engine power required to run Kubota and consumed energy were $14.27 \mathrm{hp} 23.37 \mathrm{~kW} . \mathrm{h}$ $\mathrm{ha}^{-1}$ respectively when harvested NSIC RC238 and maximum engine power required was $42.55 \mathrm{hp}$ when Kubota used to harvest NSIC RC222 with $93.49 \mathrm{~kW} . \mathrm{h} \mathrm{ha}^{-1}$ consumed energy. Kubota' lower and higher values of engine power and consumed energy obtained at higher harvesting speed. For CLAAS, minimum engine power required was $49.74 \mathrm{hp}$ to harvest NSIC RC238 at higher speed with $165.84 \mathrm{~kW} . \mathrm{h} \mathrm{ha}{ }^{-1}$ consumed energy, while the maximum engine power required was $81.50 \mathrm{hp}$ to harvest NSIC RC222 at lower speed with $316.6 \mathrm{~kW} . \mathrm{h} \mathrm{ha}{ }^{-1}$ consumed energy. Average engine power and consumed energy for both combine harvesters needed to harvest two varieties under two ranges of forward speed presented as in Figure 6 and Table 7.

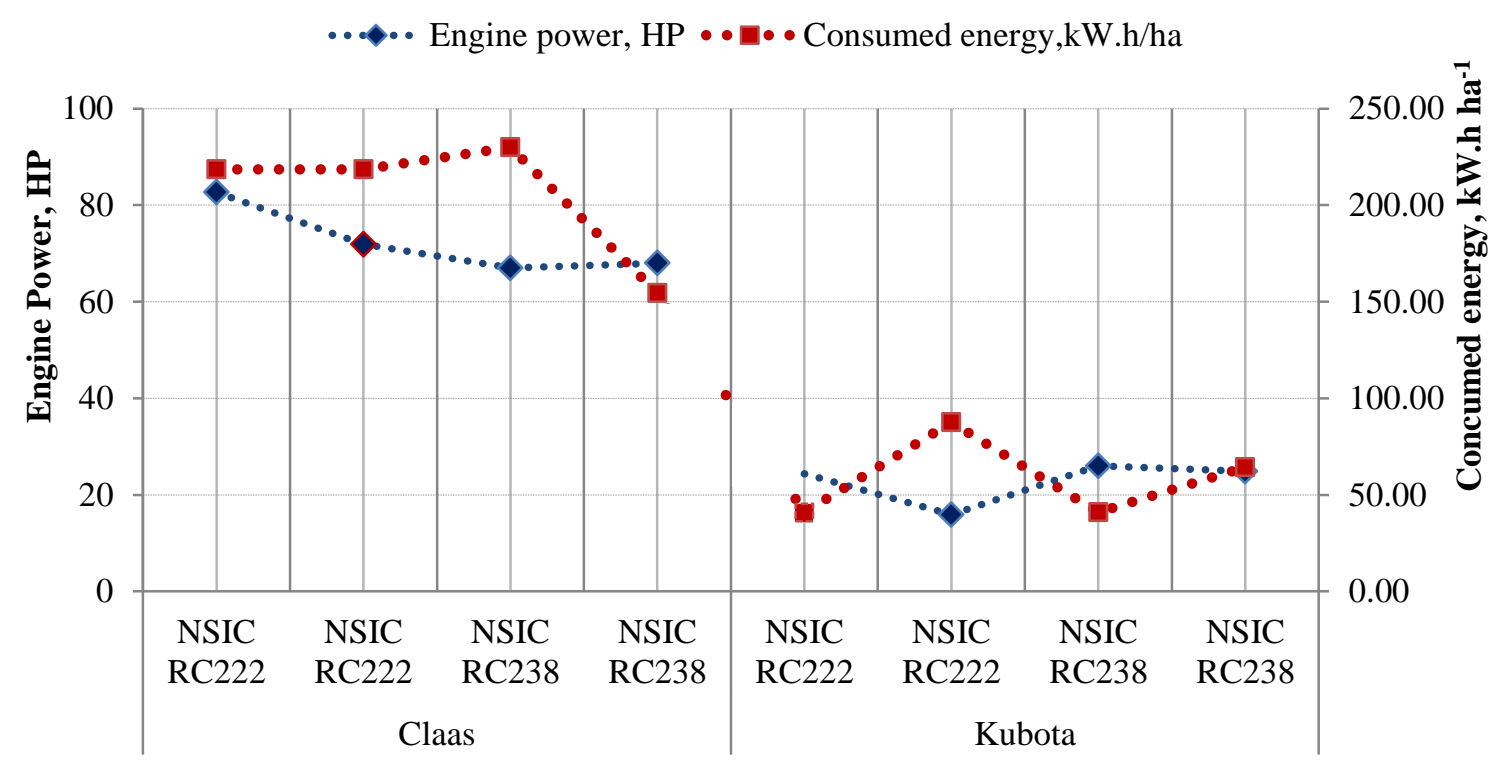

Combine harvester

Figure 6: Engine power and consumed energy 
Table 7: Average engine power and consumed energy for both combine harvesters needed to harvest two varieties under two ranges of forward speed

\begin{tabular}{|c|c|c|c|c|c|}
\hline Combine & $\begin{array}{c}\text { Average Speed } \\
\left(\mathbf{k m ~ h}^{-1}\right)\end{array}$ & $\begin{array}{c}\text { Rice } \\
\text { varieties }\end{array}$ & $\begin{array}{c}\text { Average fuel } \\
\text { consumption, } \\
\mathbf{L ~ h}^{-1} \\
\end{array}$ & $\begin{array}{c}\text { Average } \\
\text { Engine power, } \\
\text { hp }(\mathbf{k W}) \\
\end{array}$ & $\begin{array}{c}\text { Average } \\
\text { Consumed energy, } \\
\text { kW.h ha }{ }^{-1} \\
\end{array}$ \\
\hline \multirow{4}{*}{ CLAAS } & s1 (1.08) & RC 222 & 19.50 & $82.64(61.62)$ & 218.61 \\
\hline & s2 (0.94) & RC 222 & 16.96 & $71.88(53.60)$ & 218.61 \\
\hline & $\mathrm{s} 1(\mathbf{0 . 8 3})$ & RC 238 & 15.81 & $66.99(49.96)$ & 229.91 \\
\hline & $\mathrm{s} 2(\mathbf{1 . 2 5 )}$ & RC 238 & 16.03 & $67.95(50.67)$ & 154.53 \\
\hline \multirow{4}{*}{ Kubota } & s1 (2.63) & RC 222 & 5.75 & $24.38(18.18)$ & 40.90 \\
\hline & s2 (0.80) & RC 222 & 3.75 & $15.90(11.86)$ & 87.65 \\
\hline & s1 (2.80) & RC 238 & 6.13 & $25.96(19.36)$ & 40.90 \\
\hline & $\mathrm{s} 2(1.71)$ & RC 238 & 5.87 & $24.86(18.54)$ & 64.28 \\
\hline
\end{tabular}

s1: high forward speed s2: low forward speed

ANOVA showed highly significant effect of the harvester as the data of fuel consumption are varying between the two combines with no significant effect for harvesting speed and varieties. Standard deviation value was 27.208 with 0.842 coefficient of determination. Same trend obtained with comparison tests (Table 8).

Table 8: Multiple comparison tests for the variables: Tukey (HSD) / Fisher (LSD) analysis of the differences between groups with a confidence range of $95 \%$ for fuel consumption.

\begin{tabular}{|c|c|c|c|c|c|c|}
\hline Variable & \multicolumn{2}{|c|}{$\begin{array}{l}\mathbf{R} \text { (coefficient of } \\
\text { correlation) }\end{array}$} & $\begin{array}{l}\mathbf{R}^{2} \text { (coefficient } \\
\text { of } \\
\text { determination) }\end{array}$ & $\begin{array}{c}\mathbf{R}^{2} \text { adj. } \\
\text { (adjusted } \\
\text { coefficient of } \\
\text { determination) }\end{array}$ & Mean & $\begin{array}{l}\text { Standard } \\
\text { deviation }\end{array}$ \\
\hline Fuel consumption & \multicolumn{2}{|c|}{0.918} & 0.842 & 0.796 & 41.748 & 27.208 \\
\hline \multicolumn{7}{|c|}{ Comparison tests for the variable: Harvester } \\
\hline Categories & \multicolumn{2}{|c|}{ Difference } & $\begin{array}{l}\text { Standardized } \\
\text { difference }\end{array}$ & $\begin{array}{c}\text { Critical value } \\
\text { HSD/Fisher } \\
\text { (LSD) }\end{array}$ & $\begin{array}{c}\text { Pr. > Diff } \\
\text { Tukey (HSD) } \\
\text { /Fisher (LSD) }\end{array}$ & $\begin{array}{c}\text { Significant } \\
\text { (HSD)/Fisher } \\
(\mathrm{LSD})\end{array}$ \\
\hline CLAAS $*$ Kubota & \multicolumn{2}{|c|}{46.514} & 10.709 & 2.064 & $<0.0001$ & Yes \\
\hline \multicolumn{7}{|c|}{ Comparison tests for the variable: variety, Tukey (HSD) and Fisher (LSD) } \\
\hline NSIC RC $222 * \mathrm{Ns}$ & RC 238 & 6.024 & 1.387 & 2.064 & 0.178 & No \\
\hline \multicolumn{7}{|c|}{ Multiple comparison tests for the variable: Speed, Tukey (HSD) and Fisher (LSD) } \\
\hline $\mathrm{S} 1 * \mathrm{~S} 2$ & & 0.416 & 0.096 & 2.064 & 0.924 & No \\
\hline
\end{tabular}




\section{CONCLUSIONS}

Both combine harvester type and harvesting speed had significant effect on shattering losses, while both used varieties have no significant effect on shattering losses. Even with Thai combine, the differences in shattering losses for both varieties were higher than the other combines but without significance. For both rear-end losses and unstrapped losses, there was no clear trend for losses variation with the forward speed, as rear-end losses depend more on the threshing and cleaning systems and their components. All harvesting capacities tended to have its logic trend with the speed and width, but in some cases were varied due to field operational problems. With CLAAS combine, fuel consumption was higher than the amount consumed by Kubota, so, minimum engine power required to run Kubota and its consumed energy were lower too.

This study gave moderate understanding of combine's operating parameters in actual conditions to be considered to minimize losses. Determination of combine's fuel efficiency and field capacity is important for saving energy and avoidance of GHG emissions while giving farmers the ability to choose between different combine harvesters according to their conditions and needs. However, the combines were taken as used by operators and their settings were not optimized with respect to maximizing capacity and minimizing losses before the trials, in addition to unskilled operators, improper maintenance, and in-field drawbacks, so it is highly recommended to conduct more trials to track these different issues.

\section{ACKNOWLEDGMENTS}

The author would like to thank Postharvest Unit technicians and all IRRI Experiment Station staff for their invaluable support during his working time as post-doctoral research fellow. 


\section{REFERENCES}

Abdelmotaleb, I. A., H. A. El-Gendy and M. A. Hassan (2009). Combine header control. Misr J. of Ag. Eng., 26 (3): 1478-1500.

Abdul-Wohab, M. D. (2011). Current Status of Agricultural Mechanization in Bangladesh. Sustainable Agricultural Mechanization Roundtable: Moving Forward on the Sustainable Intensification of Agriculture, 8-9 December 2011. Available at: http://www.unapcaem.org/PPT/bd-index.htm.

Ahmed, N. U. and M. A. Matin (2008). Farm Mechanization for Smallholder Agriculture in Bangladesh. Proceed Ings of the Regional Workshop on Farm Mechanization for Small Holder Agriculture in SAARC Countries. Organized by SAARC Agriculture Centre and CIAE, 22-24 September 2008, SAARC, Dhaka.

Badr, M. M. (2005). Comparative study between some different combine sizes in respect to unit plot area. M.Sc. Thesis. Agric. Eng. Dept., Faculty of Agric., Zagazig Univ. Egypt.

Chang, S.F. (1986). The development and design of small rice combines. Proceedings of the International Conference on Postharvest Prevention of paddy/Rice Loss. Taipeh, Republic of China. 51-61.

CLAAS Vision (1998). CLAAS KGaA Marketing Newsletter No. 5, P: 24.

Dawe D., S. Pandey, and A. Nelson (2010). Emerging trends and spatial patterns of rice production. In: Pandey S, Byerlee D, Dawe D, Dobermann A, Mohanty S, Rozelle S, Hardy B, editors. Rice in the global economy: strategic research and policy issues for food security. Los Baños (Philippines): International Rice Research Institute. P: 15-35. 
El-Nakib, A. A, Z. Y. Abdel-Lateef, A. A. El-Messery and A. Khattab (2003): Mechanical harvesting losses in rice crop using combine harvester. Misr J. Agr. Eng., 20 (4): 889-907.

El-Sharabasy, M. M. A. (2006). Construction and manufacture a selfpropelled machine suits for cutting some grain crops to minimize losses and maximize efficiency. Misr J. Ag. Eng.,

Food and agriculture organization of the United Nations (FAO). 2014. Machinery stock (combine harvesters). Statistics Division, Food and agriculture organization of the United Nations. Available at: http://faostat3.fao.org/browse///RM/E.

Fouad, H. A., S. A. Tayel, Z. EI-Hadad, and H. Abdel-Mawla (1990). Performance of two different types of combines in harvesting rice in Egypt. Agricultural Mechanization in Asia, Africa and Latin America (AMA). 21(3): 17-22.

Gummert, M. and P.H. Hien (2013). Combine harvesting in South and Southeast Asia: Current status and trends. Proceedings of the VDIMEG Agricultural Engineering Conference on Combine Harvesters. University of Hohenheim, Germany, 12-13 September. Vol. 40, 103-122.

Hunt, D. (1983). Farm power and machinery management. $8^{\text {th }}$ Ed. Iowa state Univ., Press Ames, USA. Ames, Iowa, USA: 364-368.

Kalsirisilp, R. and G. Singh (1998). Performance evaluation of a Thai-made rice combine harvester. Proceedings of the International Agricultural Engineering Conference. Bangkok, Thailand, 7-10 December. 296-309. 
MAFF (Ministry of Agriculture, Forestry and Fisheries) (2013). The Mechanization of Cambodian Agriculture. Notes in meeting, provided by Agricultural Minister of Cambodia.

Mariano, M. J., R.Villano, and E. Fleming (2012). Factors influencing farmers' adoption of modern rice technologies and good management practices in the Philippines. Agricultural Systems 110 (2012) 41-53.

NSO (National Statistical Office) (2010). The 2008 Agriculture Intercensal Survey: Whole Kingdom, national statistical office. Ministry of Information and Communication Technology, Thailand.

Pandey S., T, Paris, and H. Bhandari (2010). Household income dynamics and changes in gender roles in rice farming. In: Pandey S, Byerlee D, Dawe D, Dobermann A, Mohanty S, Rozelle S, Hardy B, editors. Rice in the global economy: strategic research and policy issues for food security. Los Baños (Philippines): International Rice Research Institute. P: 93-111.

Saruth, Chan (2011). Cambodia Perspective on Rice Production and Mechanization in Cambodia. The Regional Seminar on Rice Production \& Mechanization, 12- 13 December, 2011 Sanya, China.

Soil Survey Staff (2010). Keys to Soil Taxonomy, 11th ed. USDA-Natural Resources Conservation Service, Washington, DC, USA.

Viet, N. Q. (2012). Current Status of Agricultural Mechanization in Vietnam. Roundtable on Developing Environmentally Sustainable Agricultural Mechanization Strategies (SAMS) for Countries in the Asia-Pacific Region 8 - 9 December 2011. Bangkok, Thailand, P: 95-97. 


\section{الملخص العربى}

\section{تحديد فواقد الحصاد والكفاعه الحقلية والطاقه المطلوبه

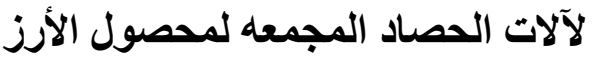 \\ د. دشاد عزيز حجازي*}

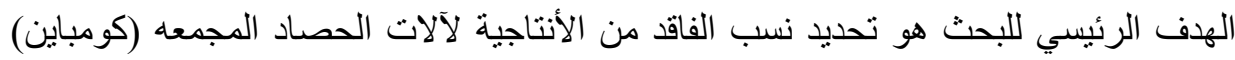

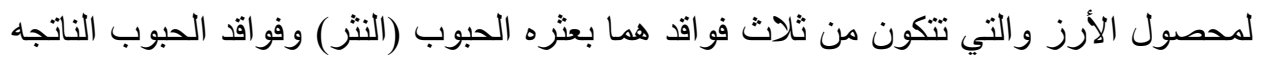

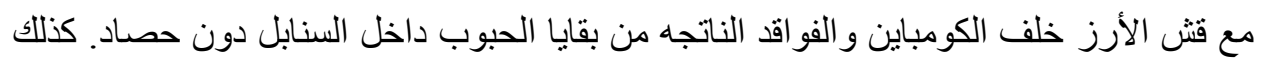

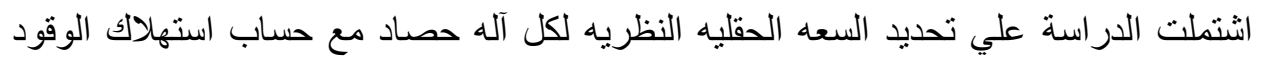
لنوعين فقط من آلات الحصاد هما كوبوتا وكلاس. وتم اجر اء التجارب في المزرعه التهابه البحثيه للمركز الدولي لبحوث الأرز في الفلبين.

وتم دراسة تـأثير كل من أربع ألات حصاد ( كوبوتا، كلاس، وينترشتيجار، وآله الحصاد

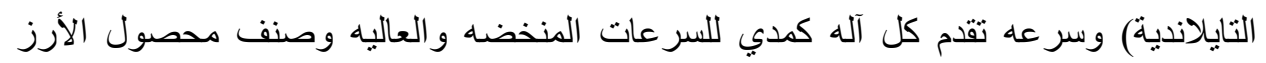

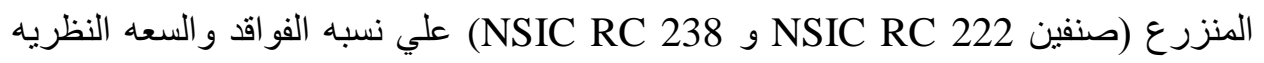

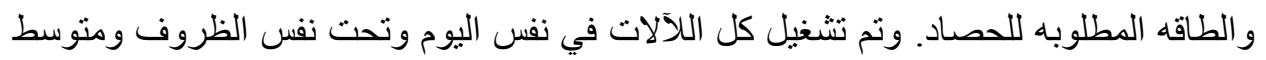

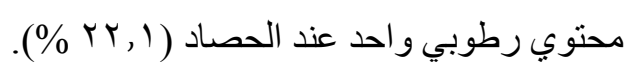

وقد أوضحث النتائج ان:

كل آلات الحصاد أعطت نسب فو اقد لبعثره الحبوب (النثر) من الأنتاجيه الكليه لكلا الصنفين و و عند سرعات مختلفه . متوسط فو اقد البعثره كانت ما ل NSIC RC 222)

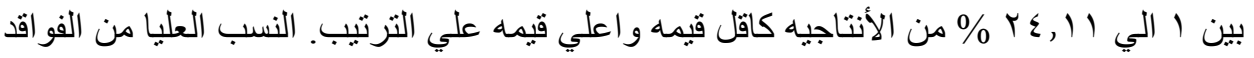
لوحظت مع السر عات الأقل ما عدا بعض القياسات لآله الحصاد التايلانديه. استخدام كلا من آله آله

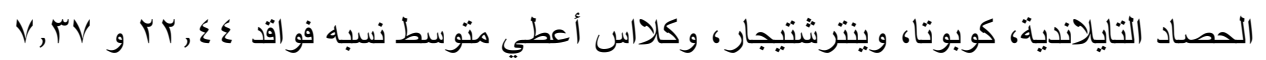
و

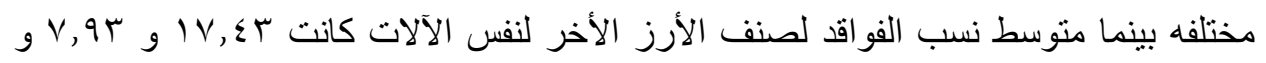

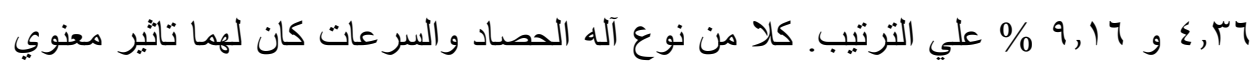

$$
\text { علي الفو اقد بعكس صنفي الأرز. }
$$

لم يكن هنالك اتجاه معين لكلا من فو اقد الحبوب الناتجه مع فش الأرز خلف الكومباين و الفو اقد

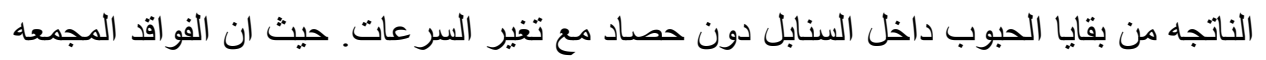

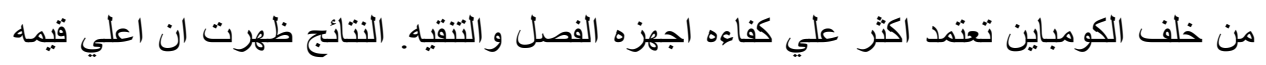

* مدرس الهندسة الزراعية ـ كلية الزراعة - جامعة كفر الثيخ. 


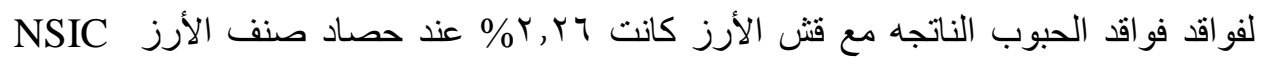

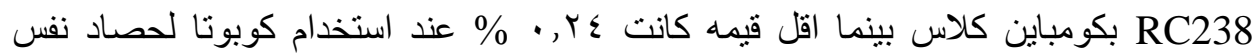

الفو اقد الناتجه من بقايا الحبوب داخل السنابل دون حصاد أظهرت قيماً اعلي في بعض الاحيان

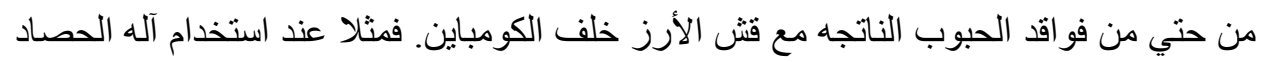

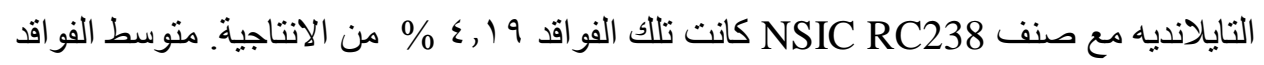

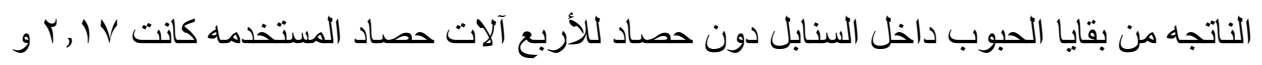

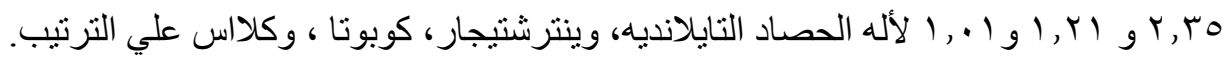

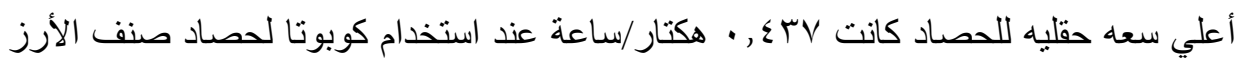
NSIC RC238

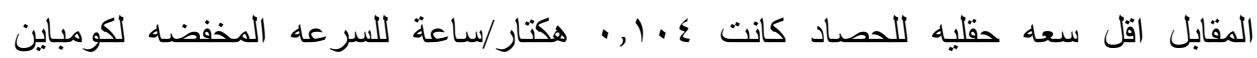

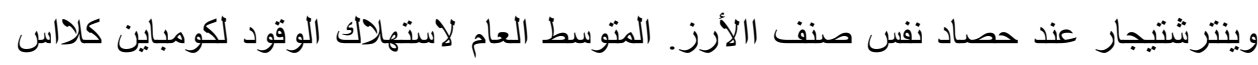

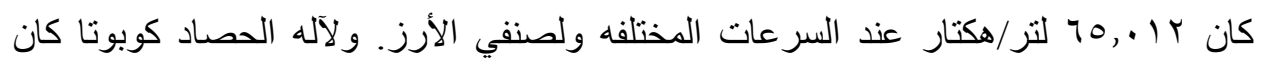

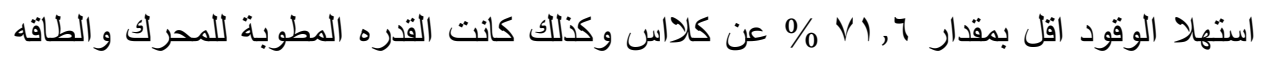

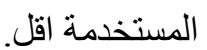

